\title{
Palaeo-redox environment analysis of Longmaxi formation shale in southern Sichuan basin by XRF and ICP-MS
}

\author{
Zhu Yiqing ${ }^{\mathrm{a}, *}$, Wang Xingzhi ${ }^{\mathrm{a}}$, Feng Mingyou ${ }^{\mathrm{a}}$, Pu Kun $^{\mathrm{b}}$, Cai Jiacheng ${ }^{\mathrm{c}}$ \\ a State Key Laboratory of Oil \& Gas Reservoir Geology and Exploitation, Southwest Petroleum University, \\ Chengdu, 610500, Sichuan, China \\ b Engineering Technology Research Institute, PetroChina Southwest Oil\&GasField Company, Chengdou, \\ 610017, Sichuan, China \\ c CCDC Drilling and Production Engineering Technology Research Institute, 618300, Guanghan, Sichuan, \\ China
}

*Corresponding author, e-mail: gk_420@163.com

Received 13 Jul 2017

Accepted 20 Mar 2018

\begin{abstract}
To build the palaeo-redox environment model of the Longmaxi Formation shale during the Silurian Rhuddanian stage in Southern Sichuan Basin, China, 20 core samples taken from wells W201 and N1 were determined by carbon-sulphur analyser, X-ray fluorescence (XRF) spectrometry, and inductively coupled plasma-mass spectrometry (ICP-MS) to test for the major and trace elements. Major elements test results shows that fragile $\mathrm{mineral}^{\mathrm{SiO}_{2}}$ component and degree of total pyritization in section $\mathrm{A}$ is greater than that of section $\mathrm{B}$, demonstrating that the reducing property of palaeo-ocean during the section A depositional stage was more intense than that of section B. U-Th ratios indicate that the palaeo-ocean during the section A depositional stage was in a dysoxic environment, and the section $\mathrm{B}$ depositional stage was in an oxic to dysoxic environment.
\end{abstract}

KEYWORDS: carbon-sulphur analyser, X-ray fluorescence, inductively coupled plasma-mass spectrometry, trace elements, $\mathrm{DOP}_{\mathrm{T}}$

\section{INTRODUCTION}

Shale gas exploration in China has begun late, and there have been no strict standards for evaluating shale gas resources applicable to China at present ${ }^{1}$. One key link for inorganic geochemical features of Longmaxi Formation shale should be discussed and formulated.

Determining sedimentary environments during shale deposition is vital to shale gas exploration and development; and geochemical tracing is an effective measure to reflect evolutions in sedimentary environments ${ }^{2}$. Series of geochemical indices, including redox value, oxygen content index, and hydrothermal origin index, have been widely applied to the study of sedimentary environment. For instance, Smolarek inspected Lower Wenlock black shale in the northern Holy Cross Mountains sedimentary environment based on the study of the major and trace elements ${ }^{3}$, and Abanda and Hannigan recovered the diagenetic history based on the REE patterns and Ce anomaly ${ }^{4}$, and Murphy studied geo- chemical characteristics of Devonian Mississippian New Albany shale in North America to identify its palaeoenvironment ${ }^{5}$.

The black organic-rich shale from the Silurian Longmaxi Formation Lower Subsection in Southern Sichuan Basin provides a typical example for the palaeo-redox environment reestablishment. For instance, Li YF carried out organic and inorganic chemical studies on Changning-Shuanghe outcrop shale samples in Southern Sichuan Basin to identify the palaeo-redox environment differences between upper and lower members of Longmaxi Formation ${ }^{6}$. However, the tests of well core samples have not been carried out yet. Thus the Science \& Technology Department of Sichuan Province provided an opportunity for us to sample well W201 (the first shale gas well in China) and well N1 cores in Southern Sichuan Basin. This study focuses on the inorganic geochemical subtle difference in fine-grained sediment, and has introduced the best redox-index applicable to the palaeo-redox restoral of the region. 


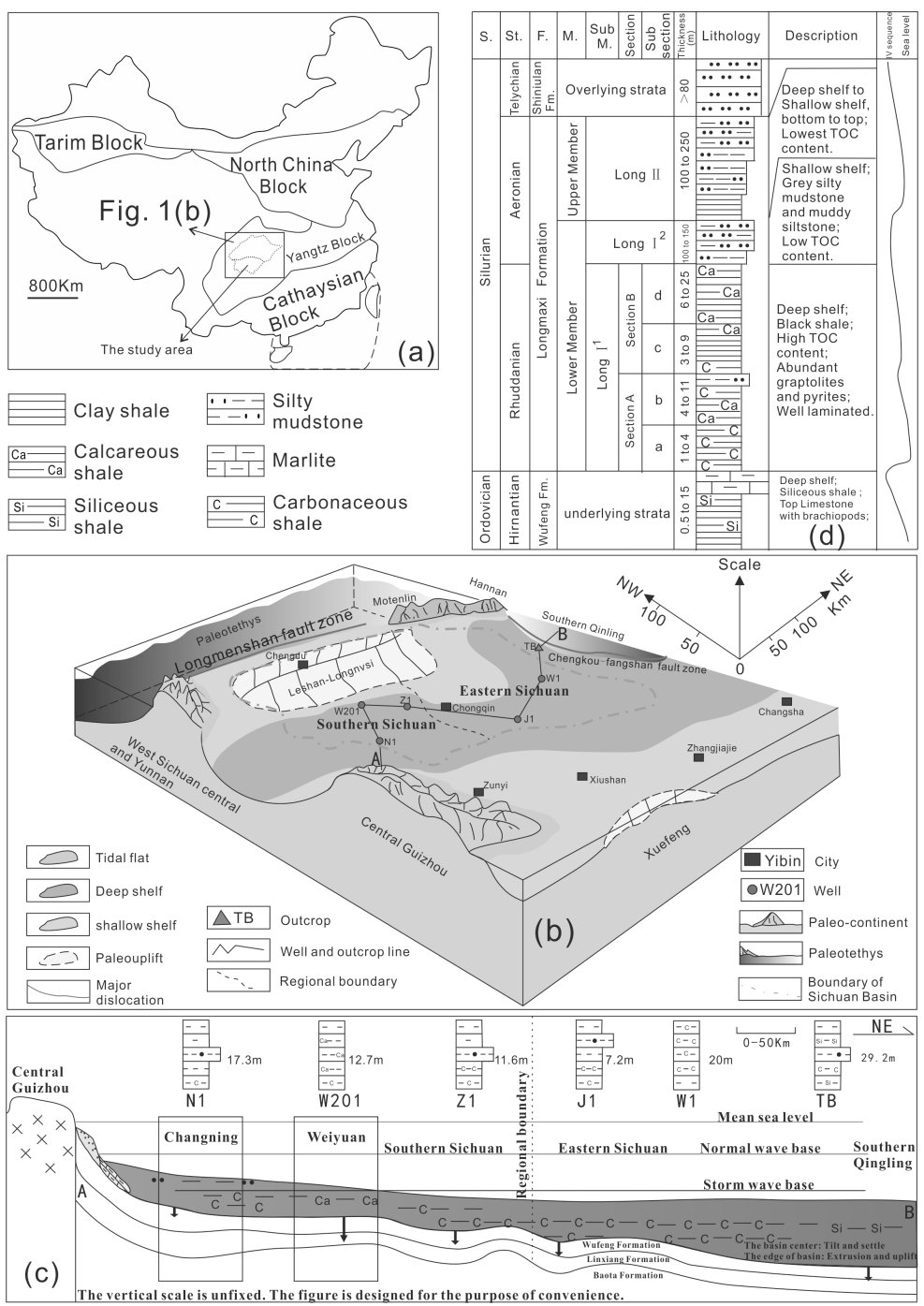

Fig. 1 (a) Geographical location of the study area, (b) deposition model of Early Silurian Longmaxi period, Sichuan basin (modified from Ref. 10), (c) Long $\mathrm{I}^{1}$ Submember deposition model differences between Eastern Sichuan and southern Sichuan, and (d) section classification scheme and stratigraphic column.

\section{GEOLOGICAL SETTING}

Lower Palaeozoic Longmaxi Formation organic-rich shale, widely distributed in the Sichuan Basin and periphery of Sichuan Basin in the Yangtze Craton Block, is the only shale gas production layer in China $^{7}$ (Fig. 1a). This marine shale stratum palaeoenvironment used to be a deep continental shelf surrounded by a series of palaeo-continent and palaeo-uplift, which is characterized by low energy, high sedimentation rate, huge sedimentary thickness, and a relatively complete preservation of palaeontology with a wide distribution in the entire basin $^{8}$ (Fig. 1b). The research area is located in the south of the Sichuan basin and the main shale gas exploration and development areas are Changning and Weiyuan block (Fig. 1c).

Previous studies suggested that the Longmaxi Formation could be divided into upper and lower members based on characteristics from rock facies, palaeontological facies, and $\log$ facies ${ }^{9}$. However, due to the demand of actual large-scale exploitation, the Long $\mathrm{I}^{1}$ Submember which belongs to Lower Member can be further divided into 4 subsections, named a, b, c, and $d^{10}$. Furthermore, the a and b subsections can be reduced to the section $\mathrm{A}$, while the $c$ and $d$ subsections can be reduced to section $B$ according to IV level cyclic sedimentation sequence (Fig. 1d). Besides, the section A is the main producing layer at present. This study mainly discusses 
the features of inorganic geochemical pattern and the differences between section A and B reflected in palaeo-redox indices.

\section{SAMPLING AND METHODS}

For Weiyuan block, fourteen shale core mud-stone samples, taking from Long I ${ }^{1}$ Submember of the well W201, free from paint and pyrite pollution, have been tested for major and trace elements. Sampling depth ranges from 1501-1542 $\mathrm{m}$, and due to the fact that the section $\mathrm{A}$ has thinner thickness, sampling interval is $1-2 \mathrm{~m}$ in section $\mathrm{A}, 5-6 \mathrm{~m}$ in section $\mathrm{B}$ (sample serial numbers are W1 1-14, and W1 1-6 for section A, W1 7-14 for section B). For Changning Block, six shale core mud-stone samples, taking from Long $\mathrm{I}^{1}$ Submember of the well N1 have been tested for major and trace elements, sampling depth ranges from 2367-2394 $\mathrm{m}$ (sample serial numbers are N1 1-6, and N1 1-3 for section A, N1 4-6 for section $\mathrm{B}$ ), the test data and other logging data are provided by the Southwest Oil \& Gas Field CompanyExploration Exploration and Development Research Institute).

Total sulphur (TS) analysis test has been conducted in Southwest Oil \& Gas Field Company-Exploration and Development Research Institute Analysis and Test Centre (Chengdu), while the major and trace element analysis tests have been conducted in the ALS Chemex (Guangzhou). All samples have been ground to 200 mesh powder and kept in desiccators before chemical analysis.

TS has been analysed by CS-400 analyser at a temperature of $18{ }^{\circ} \mathrm{C}$ and a humidity of $65 \%$ $\mathrm{RH}$. Major elements have been analysed by X-ray fluorescence (XRF) with a detection limit of $0.01 \%$, a prepared sample fused with lithium metaboratelithium tetraborate flux which also includes an oxidizing agent $\left(\mathrm{LiNO}_{3}\right)$ and then poured into a platinum mould. The resultant disk is in turn analysed by XRF spectrometry. Trace elements have been analysed by inductively coupled plasma-mass spectrometry (ICP-MS), a prepared sample added to lithium metaborate flux $(0.9 \mathrm{~g})$ mixed well, then dissolved in $100 \mathrm{ml}$ of $4 \% \mathrm{HNO}_{3} / 2 \% \mathrm{HCl}_{3}$ solution. It is then analysed by ICP-MS. Results are corrected for spectral interelement interferences. Besides, due to the high content of organic matter, the samples have been calcined at $750^{\circ} \mathrm{C}$ before the XRF and ICPMS test to avoid test-error by additional elements content in residual kerogen.

The degree of pyritization (DOP), the ratio of iron in pyrite to total active iron, is the general palaeo-redox index. As the DOP is similar to the ratio of iron in pyrite to total iron $\left(\mathrm{DOP}_{\mathrm{TFe}_{2} \mathrm{O}_{3}}\right)$, this study uses $\mathrm{DOP}_{\mathrm{T}}\left(\mathrm{DOP}_{\mathrm{TFe}_{2} \mathrm{O}_{3}}\right)$ to replace the DOP based on the assumption that the TS exists in the form of pyrite when iron content in pyrite is estimated. The $\mathrm{DOP}_{\mathrm{T}}$ is estimated as ${ }^{11}$ :

$$
\mathrm{DOP}_{\mathrm{T}}=\frac{55.85}{64.16} \mathrm{TS} / \mathrm{TFe}_{2} \mathrm{O}_{3},
$$

where, " 55.85 " and "64.16" are the atomic mass of iron and sulphur in pyrite, respectively.

The trace element in sediments are usually composed of the authigenic and non-authigenic (terrigenous detrital) component. However, only the former can reflect the real palaeoenvironment states. To eliminate the interference of terrigenous detrital components to authigenic trace elements, the general method uses element $\mathrm{Al}$ to normalize the trace element content. An enrichment fraction $(\mathrm{EF})$ is calculated as ${ }^{12}$ :

$$
\mathrm{EF}=\frac{(\mathrm{X} / \mathrm{Al})_{\mathrm{s}}}{(\mathrm{X} / \mathrm{Al})_{\mathrm{b}}},
$$

where $\mathrm{X}$ is the concentration of elements, "s" is for the sample value, and " $\mathrm{b}$ " is for the background value.

The authigenic $\mathrm{U}$ concentration $(\delta \mathrm{U})$ can be represented by an empirical formula as ${ }^{13}$ :

$$
\delta \mathrm{U}=\frac{\mathrm{U}}{(\mathrm{U}+\mathrm{Th} / 3) / 2},
$$

where $\mathrm{Th} / 3$ represents the $\mathrm{U}$ content carried by terrigenous detritus.

\section{RESULTS}

Results of the major and trace elemental data and rare earth elements content and calculated results of well W201 and N1 for palaeoenvironment analysis are given in Table 1 and Table 2, respectively. Other major and trace elements test data are not shown.

\section{Major elements}

For the two sections, the abundance of major elements did not show obvious regularities or correlations (Fig. 2a). However, the ternary plot of major elements $\left(\mathrm{SiO}_{2}, \mathrm{Al}_{2} \mathrm{O}_{3}\right.$, and $\left.\mathrm{CaO}\right)$ shows that the samples from section A contains more $\mathrm{SiO}_{2}$ component than that of section B (Fig. 2b).

\section{Trace elements}

Fig. 3 shows vertical distributions of the samples trace elements content normalized by element $\mathrm{Al}$ 
Table 1 Analytical and calculated results of major elemental components of shale in Longmaxi formation, Sichuan basin, China.

\begin{tabular}{|c|c|c|c|c|c|c|c|c|c|c|c|}
\hline \multirow[t]{2}{*}{$\mathrm{Sec}$} & \multirow[t]{2}{*}{ No. } & \multirow{2}{*}{$\begin{array}{l}\text { Depth } \\
\text { (m) }\end{array}$} & \multirow[t]{2}{*}{ TS } & \multicolumn{5}{|c|}{ Major elements content (\%) } & \multicolumn{3}{|c|}{ Calculated results } \\
\hline & & & & $\mathrm{Al}_{2} \mathrm{O}_{3}$ & $\mathrm{CaO}$ & $\mathrm{SiO}_{2}$ & $\mathrm{TFe}_{2} \mathrm{O}_{3}$ & $\mathrm{TiO}_{2}$ & $\mathrm{DOP}_{\mathrm{T}}$ & $\mathrm{TFe}_{2} \mathrm{O}_{3} / \mathrm{TiO}_{2}$ & $\mathrm{SBC}^{*}$ \\
\hline \multirow[t]{9}{*}{ A } & W1-1 & 1542 & 4.1 & 6.2 & 2.31 & 76.53 & 5.22 & 0.38 & 0.68 & 13.74 & 85.04 \\
\hline & W1-2 & 1540.9 & 3.86 & 6.08 & 2.12 & 76.83 & 6.12 & 0.21 & 0.55 & 29.14 & 85.03 \\
\hline & W1-3 & 1539.7 & 2.18 & 8.62 & 6.13 & 63.08 & 3.03 & 0.41 & 0.63 & 7.39 & 77.83 \\
\hline & W1-4 & 1538 & 2.7 & 9.41 & 7.84 & 62.1 & 4.66 & 0.42 & 0.5 & 11.1 & 79.35 \\
\hline & W1-5 & 1537 & 3.1 & 8.74 & 8.95 & 67.1 & 3.76 & 0.43 & 0.72 & 8.74 & 84.79 \\
\hline & W1-6 & 1536 & 1.87 & 9.98 & 11.95 & 47.53 & 2.23 & 0.45 & 0.73 & 4.96 & 69.46 \\
\hline & N1-1 & 2394 & 3.25 & 9.3 & 11.4 & 69.6 & 4.1 & 0.61 & 0.69 & 6.72 & 90.3 \\
\hline & $\mathrm{N} 1-2$ & 2390 & 2.37 & 20.9 & 12.6 & 59.9 & 2.9 & 0.54 & 0.71 & 5.37 & 93.4 \\
\hline & N1-3 & 2385 & 2.13 & 29.5 & 9.4 & 53.8 & 2.5 & 0.39 & 0.74 & 6.41 & 92.7 \\
\hline \multirow[t]{11}{*}{ B } & W1-7 & 1532.03 & 4.31 & 14.53 & 5.17 & 53.29 & 5.61 & 0.38 & 0.67 & 14.76 & 72.99 \\
\hline & W1-8 & 1530 & 2.11 & 8.28 & 16.15 & 35.53 & 3.96 & 0.35 & 0.46 & 11.31 & 59.96 \\
\hline & W1-9 & 1527 & 1.38 & 8.82 & 17.15 & 34.36 & 2.91 & 0.4 & 0.41 & 7.28 & 60.33 \\
\hline & W1-10 & 1524.14 & 1.87 & 8.91 & 21.8 & 30.62 & 3 & 0.39 & 0.54 & 7.69 & 61.33 \\
\hline & W1-11 & 1517.68 & 1.93 & 11.08 & 7.38 & 55.67 & 3.93 & 0.54 & 0.43 & 7.28 & 74.13 \\
\hline & W1-12 & 1512.19 & 1.22 & 12.38 & 4.99 & 61.49 & 4.36 & 0.37 & 0.24 & 11.78 & 78.86 \\
\hline & W1-13 & 1507 & 1.14 & 12.94 & 6.61 & 54.11 & 2.78 & 0.46 & 0.36 & 6.04 & 73.66 \\
\hline & W1-14 & 1501 & 1.32 & 11.56 & 14.25 & 43.61 & 3.55 & 0.39 & 0.32 & 9.1 & 69.42 \\
\hline & N1-4 & 2378 & 1.84 & 21.5 & 9.43 & 46.3 & 3.91 & 0.41 & 0.41 & 9.54 & 77.23 \\
\hline & N1-5 & 2372 & 1.9 & 22.4 & 8.72 & 50.5 & 4.23 & 0.43 & 0.39 & 9.84 & 81.62 \\
\hline & N1-6 & 2367 & 1.64 & 29 & 7.65 & 44.7 & 3.86 & 0.49 & 0.37 & 7.88 & 81.35 \\
\hline
\end{tabular}

* Shale basic component $=\mathrm{Al}_{2} \mathrm{O}_{3}+\mathrm{CaO}+\mathrm{SiO}_{2}$.

Table 2 Analytical and calculated results of trace and rare earth elemental components of shale in Longmaxi formation, Sichuan basin, China.

\begin{tabular}{|c|c|c|c|c|c|c|c|c|c|c|c|c|c|c|c|c|c|c|}
\hline \multirow[t]{2}{*}{$\overline{\mathrm{Sec}}$} & \multirow[t]{2}{*}{ No. } & \multirow{2}{*}{$\begin{array}{c}\text { Depth } \\
(\mathrm{m})\end{array}$} & \multicolumn{7}{|c|}{ Trace elements content $(\mu \mathrm{g} / \mathrm{g})$} & \multicolumn{2}{|c|}{ REE $(\mu g / g)$} & \multicolumn{7}{|c|}{ Calculated results } \\
\hline & & & $\mathrm{U}$ & $\mathrm{V}$ & $\mathrm{Cr}$ & Co & $\mathrm{Ni}$ & Mo & $\overline{T h}$ & $\mathrm{Y}$ & Ho & $\mathrm{U} / \mathrm{Th}$ & $\delta \mathrm{U}$ & $\mathrm{V} / \mathrm{Cr}$ & $\mathrm{U} / \mathrm{Mo}$ & $\mathrm{Ni} / \mathrm{Co}$ & $\mathrm{V} / \mathrm{V}+\mathrm{Ni}$ & $\mathrm{Y} / \mathrm{Ho}$ \\
\hline \multirow[t]{9}{*}{ A } & W1-1 & 1 & 9.1 & 132 & 36 & 12.4 & 74.6 & 20.2 & 8.4 & 19.2 & 0.65 & 1.08 & 1.52 & 3.67 & 0.45 & 6.02 & .04 & 29.5 \\
\hline & W1-2 & 1541 & 8.4 & 141 & 32 & 12.3 & 68 & 19.4 & 7.8 & 24.4 & 0.82 & 1.08 & 1.53 & 4.41 & 0.43 & 5.53 & .67 & 29.8 \\
\hline & W1-3 & 1540 & 11.1 & 146 & 33 & 12.7 & 56 & 22.6 & 12.7 & 30.9 & 1.04 & 0.87 & 1.45 & 4.42 & 0.49 & 4.41 &.$/ 2$ & 29.7 \\
\hline & W1-4 & 1538 & 13.4 & 143 & 35 & 12.9 & 68 & 21.3 & 13.0 & 33.5 & 1.07 & 1.03 & 1.51 & 4.09 & 0.63 & 5.27 & .08 & 31.3 \\
\hline & W1-5 & 1537 & 13.3 & 139 & 31 & 13.1 & 77 & 18.5 & 12.8 & 22.4 & 0.73 & 1.04 & 1.51 & 4.48 & 0.72 & 5.88 & 0.64 & 30.7 \\
\hline & W1-6 & 1536 & 14.2 & 134 & 29 & 14.6 & 62 & 16 & 13.9 & 40.5 & 1.25 & 1.02 & 1.51 & 62 & 38 & 4.25 & 0.68 & 32.4 \\
\hline & N1-1 & 2394 & 28.6 & 361 & 48 & 9.2 & 142 & 98.4 & 8.8 & 23.1 & 0.72 & 3.24 & 1.81 & 7.60 & 0.29 & 5.49 & .72 & 32.1 \\
\hline & N1-2 & 2390 & 12.5 & 140 & 31 & 7.8 & 80.4 & 38.7 & 7.0 & 16.5 & 0.53 & 1.80 & 1.69 & 4.49 & 0.32 & 10.36 & 0.64 & 31.1 \\
\hline & N1-3 & 2385 & 10.3 & 146 & 34 & 8.5 & 59.6 & 34.5 & 8.2 & 17.3 & 0.55 & 1.25 & 1.58 & 4.29 & 0.30 & .00 & .71 & 31.5 \\
\hline \multirow{11}{*}{ 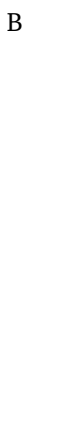 } & & 1532 & 12.7 & 90 & 25 & 16.2 & 51.8 & 22.9 & 23.6 & 26.1 & 0.82 & 0.54 & 1.24 & 3.60 & 0.55 & 3.20 & 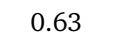 & 31.8 \\
\hline & W1-8 & 1530 & 8.2 & 89 & 27 & 11.9 & 53 & 12.1 & 11.4 & 21.7 & 0.71 & 0.72 & 1.37 & 3.30 & 0.68 & 4.45 & 0.63 & 30.6 \\
\hline & W1-9 & 1527 & 11.8 & 91 & 33 & 15.3 & & 16.9 & 13 & 35.9 & 1.01 & 0.91 & 1.46 & 2.76 & 0.70 & 4.18 & 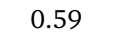 & 35.5 \\
\hline & W1-10 & 1524 & 9.1 & 76 & 24 & 9.1 & 49.8 & 7.2 & 11.6 & 41.3 & 1.17 & 0.78 & 1.40 & 3.17 & 1.26 & 5.47 & 0.60 & 35.3 \\
\hline & W1-11 & 1518 & 14.7 & 99 & 36 & 13.9 & 74.4 & 28 & 16.9 & 28.2 & 0.96 & 0.87 & 1.45 & 2.75 & 0.53 & 5.35 & 0.57 & 29.4 \\
\hline & W1-12 & 1512 & 5.4 & 90 & 26 & 10.3 & 43.9 & 5.2 & 11.9 & 25.3 & 0.79 & 0.45 & 1.15 & 3.46 & 1.04 & 4.26 & $0.6 \%$ & 32.0 \\
\hline & W1-13 & 1507 & 8.8 & 99 & 37 & 15.9 & 63 & 9.4 & 14.3 & 18.2 & 0.6 & 0.62 & 1.30 & 2.68 & 0.94 & 3.96 & 0.61 & 30.3 \\
\hline & W1-14 & 1501 & 3.5 & 78 & 30 & 13 & 53.6 & 2.63 & 11.9 & 28.2 & 0.93 & 0.30 & 0.94 & 2.60 & 1.34 & 4.12 & 0.59 & 30.3 \\
\hline & N1-4 & 2378 & 22.2 & 158 & 36 & 7.8 & 97.8 & 46.2 & 18.8 & 26.7 & 0.91 & 1.18 & 1.56 & 4.39 & 0.48 & 12.54 & 0.62 & 29.3 \\
\hline & N1-5 & 2372 & 6.4 & 140 & 32 & 8.6 & 57.2 & 13.1 & 14.5 & 19.9 & 0.73 & 0.44 & 1.14 & 4.38 & 0.49 & 6.65 & 0.71 & 27.3 \\
\hline & N1-6 & 2367 & 5.6 & 111 & 33 & 8.9 & 51.5 & 10.3 & 15.1 & 20 & 0.7 & 0.37 & 1.05 & 3.36 & 0.54 & 5.79 & 0.68 & 28.6 \\
\hline
\end{tabular}



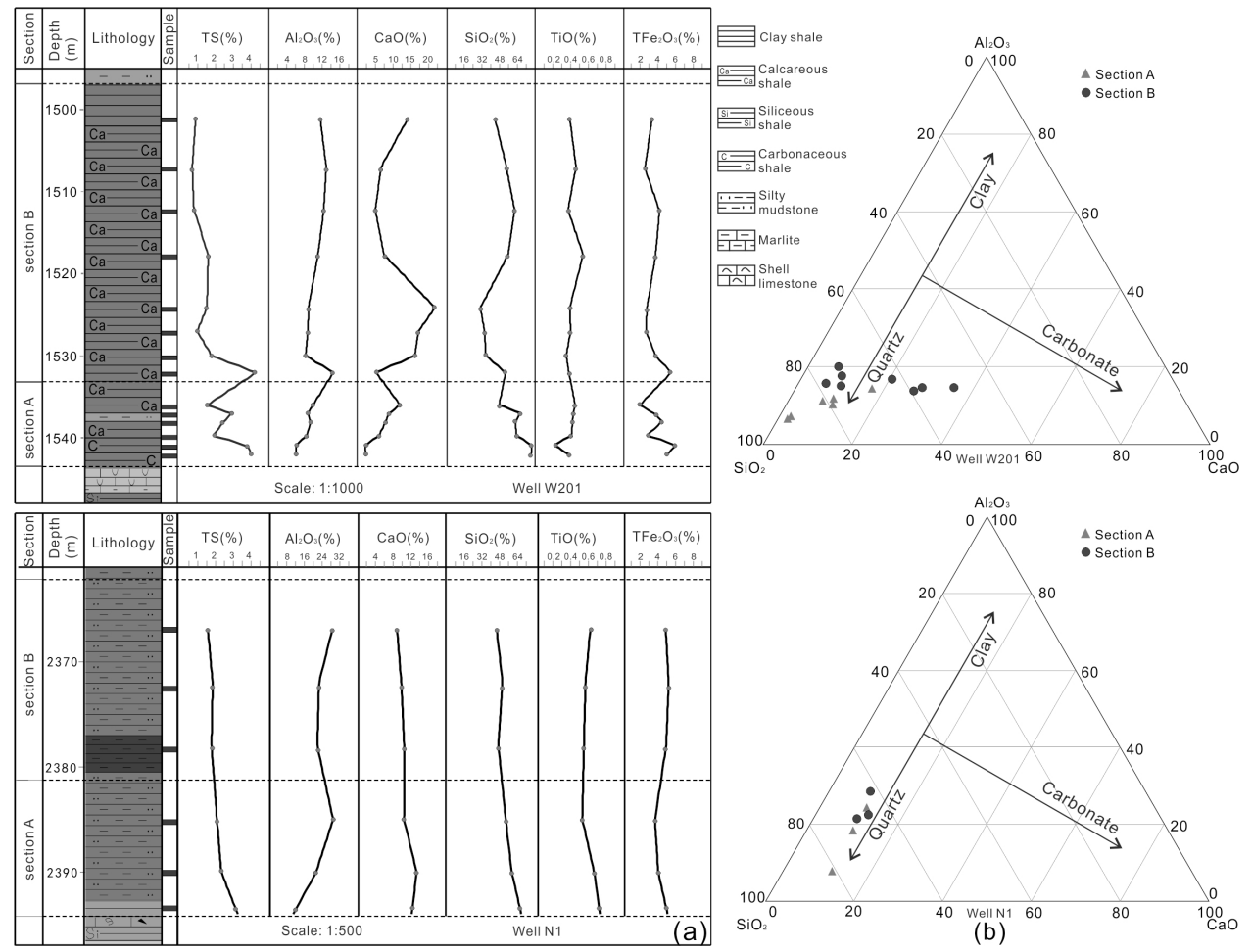

Fig. 2 (a) Variation characteristics of TS and major elements of section A and section B in Longmaxi formation for well w201 and N1, and (b) $\mathrm{Al}_{2} \mathrm{O}_{3}, \mathrm{SiO}_{2}$, and $\mathrm{CaO}$ ternary plot for section A and section B from well w201 and N1.
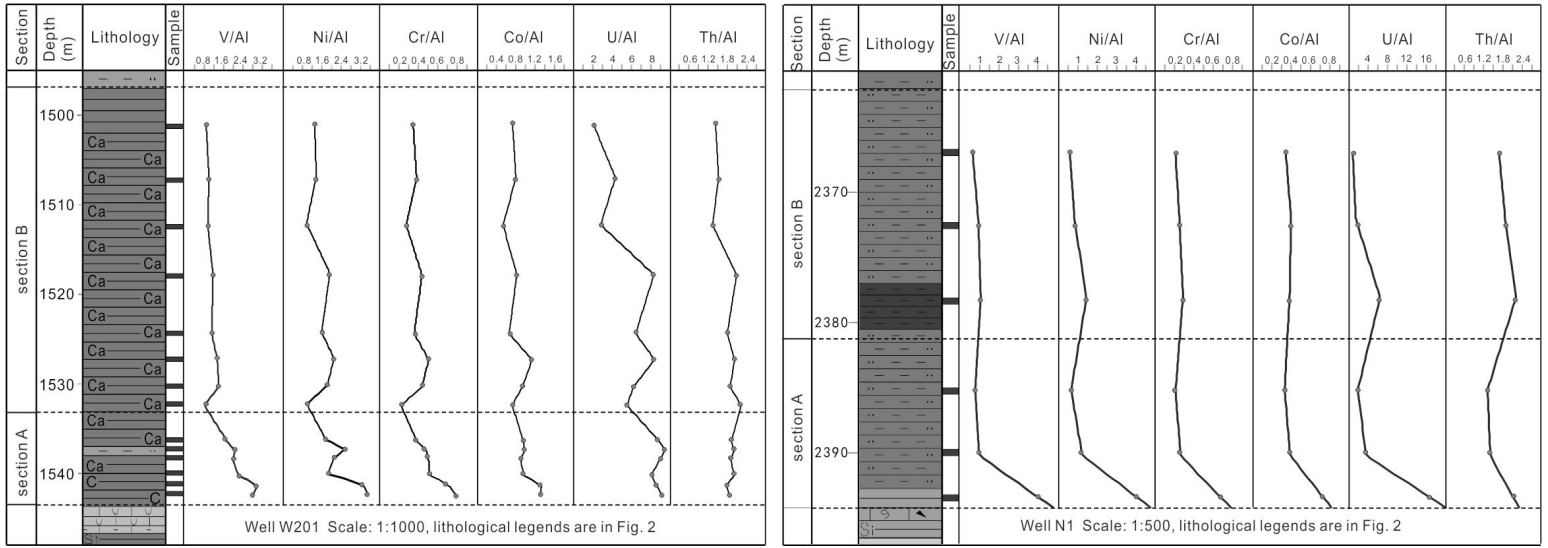

Fig. 3 Vertical distributions of Al-normalized (NASC) trace elements of section A and section B in Longmaxi formation for well w201 and N1.

compared with North American Shales Composite ${ }^{14}$ : Elements $\mathrm{V}, \mathrm{Ni}, \mathrm{U}$, and $\mathrm{Th}$ all show strong enrichment $(\mathrm{EF}>1)$. All the element $\mathrm{EF}$ value of samples from section A are greater than that of section B. Besides, except for element Th of Well W201. The vertical variation is very consistent across the normalized elements $\mathrm{V}, \mathrm{Ni}, \mathrm{Cr}$, Co, and $\mathrm{U}$, suggesting that the reasons for controlling of the enrichment of these elements are probably the same. Furthermore, the vertical characteristics of these normalized elements are similar to the trace element test results from the Changning-Shuanghe field $^{6}$, indicating that the weathering did not affect too much these trace elements distribution.

\section{DISCUSSION}

Before applying the major and trace elements pattern to the study of palaeoenvironment, impacts by 
non-authigenic elements, namely, terrigenous detrital infusion, hydrothermal fluid, and palaeontology sources, were removed.

The $\mathrm{Y} / \mathrm{Ho}$ values of all samples ranging from 29.38-35.54 were greater than 24 but less than 44 , indicating that the samples did not have or only had a little terrigenous detrital infusion during section $\mathrm{A}$ and section $\mathrm{B}$ depositional periods ${ }^{15}$. The $\mathrm{TFe}_{2} \mathrm{O}_{3} / \mathrm{TiO}_{2}$ values of all samples are ranged from 4.96-14.76 and are all less than 20 (except for W1-

2) (Table 1), suggesting that the Rhuddanian stage was subject to normal seawater ${ }^{16}$. Besides, the section A and section B strata have many palaeontological organisms, such as sponge spicules and radiolarian, which clearly affect $\mathrm{SiO}_{2}$ content (Fig. 4a). However, the trace elements in the palaeontological organisms as trace nutrients are quite few, barely affecting total trace elements content ${ }^{17}$.

\section{Palaeo-environment constrained from major element}

$\mathrm{SiO}_{2}$ has three origins: produced by terrigenous clastic supply, fossil bones remains, and clay minerals transformation ${ }^{18}$. As mentioned above, the $\mathrm{SiO}_{2}$ caused by terrigenous clastic supply has been removed. Besides, Wang calculated the excess silicon content in the Longmaxi Formation of W201 well and proved that the excess $\mathrm{SiO}_{2}$ mainly originates from organics which accounts for not more than 5\% to the total ${ }^{7}$. As the organic matter was burned away in the test, the display content of authigenic $\mathrm{SiO}_{2}$ in the test data can only come from the process of clay minerals transformation (Fig. 4b). The result is that more $\mathrm{SiO}_{2}$ dissolved out from the process of transforming smectite or kaolinite to illite as the burial depth and palaeo-temperature increase. Hence the result of the ternary plot in Fig. $2 \mathrm{~b}$ can demonstrate that section A experienced higher burial depth and palaeo-temperature than section B during the diagenesis, which is consistent with geological background, but overall it may not reflect the palaeoenvironment.

In that case, the $\mathrm{DOP}_{\mathrm{T}}$ can be preferred to reflect the reduction intensity of palaeoenvironment. The $\mathrm{DOP}_{\mathrm{T}}$ values of samples from section A are greater than that of section $\mathrm{B}$, indicating that the reduction tense of palaeo-ocean during section A deposition period is stronger than that of section B. Furthermore, in general, the value of $\mathrm{DOP}_{\mathrm{T}}<0.42$ indicates an oxic environment, in the range of $0.42-0.75$ a dysoxic environment, and $\mathrm{DOP}_{\mathrm{T}}>0.75$ an anoxic environment ${ }^{19}$. Section A of well W201 and N1 has a $\mathrm{DOP}_{\mathrm{T}}$ values of $0.50-0.74$, with an average of
0.66 , referring to a dysoxic environment and section B $0.24-0.67,0.42$, an oxic to dysoxic environment (Table 1).

\section{Palaeo-environment constrained from trace element}

Ratios of redox sensitive elements are the ideal indices for the recovery of palaeo-ocean redox states. For instance, the sediments would be rich in $\mathrm{U}^{4+}$ in a strong reducing environment and $\mathrm{U}^{6+}$ in an oxidizing environment, while Th content would not be affected by the redox-conditions of water. Hence the $\mathrm{U} / \mathrm{Th}$ ratio can reflect the redox condition during deposition. In general, the ratio of $\mathrm{U} / \mathrm{Th}>1.25$ indicates an anoxic environment, in the range of $0.75-1.25$ a dysoxic environment, and $\mathrm{U} / \mathrm{Th}<0.75$ an oxic environment ${ }^{20}$. Section A of well W201 and $\mathrm{N} 1$ has a U/Th ratio of $0.87-1.80$ (except for N11 ), with an average of 1.15 , suggesting a dysoxic environment, while samples from section B have $0.30-1.18,0.65$, suggesting an oxic to dysoxic environment (Fig. 5a, Table 2), which conforms to the $\mathrm{DOP}_{\mathrm{T}}$ analysis results. Besides, $\delta \mathrm{U}$ can reflect the state of palaeo-ocean. In general, $\delta \mathrm{U}<1$ indicates a normal ocean and $\delta \mathrm{U}>1$ a reducing palaeo-ocean. Section A of well W201 has a $\delta U$ value of 1.45-1.81, with an average of 1.57 , referring to a reducing palaeo-ocean and samples from section B 0.94-1.56, 1.28 , a weaker-reducing palaeo-ocean.

Like the $\mathrm{U} / \mathrm{Th}$ ratio and $\delta \mathrm{U}$, previous studies have established the standard for elemental ratios of $\mathrm{V} /(\mathrm{V}+\mathrm{Ni}), \mathrm{Ni} / \mathrm{Co}$ and $\mathrm{V} / \mathrm{Cr}$ which were used as redox indices ${ }^{21,22}$. A comprehensive plot using these redox indices was presented in Fig. 5b. For well W201, Ni/Co, and U/Th plot gives a consistent result of a clear transition from dysoxic to oxic environment which can be observed from section A to section B samples, whereas $\mathrm{V} / \mathrm{Cr}$ and $\mathrm{U} / \mathrm{Th}$ plot shows a relative higher reducing level of anoxic to dysoxic environment from section A to section B samples. However, $\mathrm{V} /(\mathrm{V}+\mathrm{Ni})$ and $\mathrm{U} / \mathrm{Th}$ plot shows that the palaeo-redox difference between section $\mathrm{A}$ and section B is not significant. The reason for this may be that the elements $\mathrm{V}$ and $\mathrm{Ni}$ are mainly in the form of porphyrin compounds in kerogen, whereas the organics were burned away before ICP-MS test. Thus the test results of elements $\mathrm{V}$ and Ni may have the errors. Besides, the plots form of the all redox indices above for Well $\mathrm{N} 1$ is consistent with that for Well W201.

In addition, Mo has been used as an index of oxygen content ${ }^{23}$. In general, a high U/Mo ratio indicates a constant oxic environment. The con- 

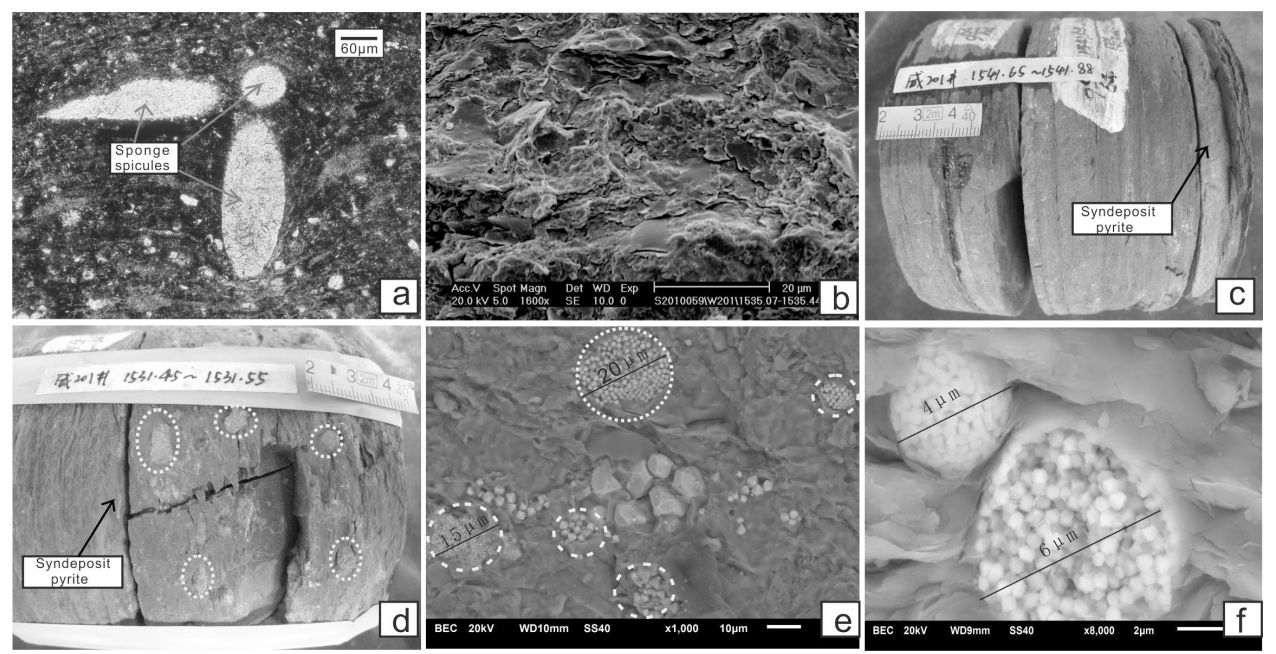

Fig. 4 (a) Sponge spicules, $10 \times 10(-), 1508.83 \mathrm{~m}$, well w201, (b) illite on the surface of particles $1600 \times$, SEM, $1535.7 \mathrm{~m}$, well W201 (energy spectrum tested), (c) synsedimentary pyrite layer, $6 \mathrm{~mm}$, section A, 1541.65-1541.88 m, well w201, (d) synsedimentary pyrite layer, $1 \mathrm{~mm}$, and pyrite formed by formation water (dotted part), section B, 1531.45-1531.55 m, well w201, (e) coalball-shaped pyrites (dotted part), 1000×, SEM, section A, Changning area, and (f) coalball-shaped pyrites, 8000×, SEM, section B, Changning area.
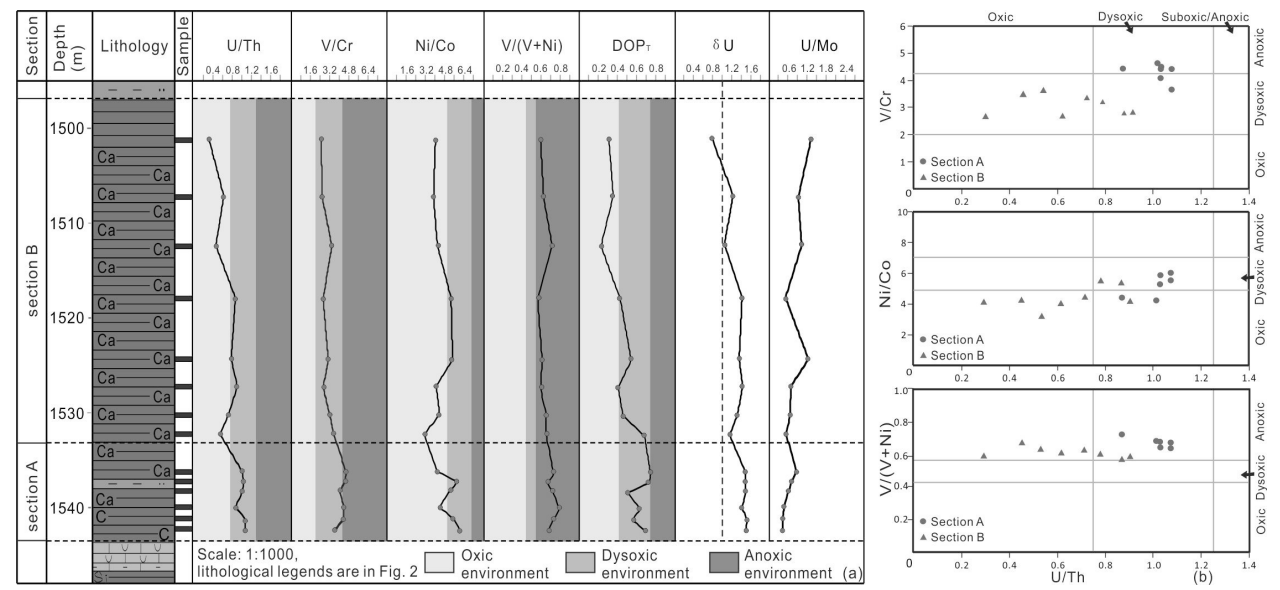

Fig. 5 (a) Variation characteristics of $\delta \mathrm{U}, \mathrm{DOP}_{\mathrm{T}}$ and $\mathrm{U} / \mathrm{Th}, \mathrm{V} / \mathrm{Cr}, \mathrm{Ni} / \mathrm{Co}, \mathrm{V} /(\mathrm{V}+\mathrm{Ni}), \mathrm{U} / \mathrm{Mo}$ ratios of section $\mathrm{A}$ and section B in Longmaxi formation for well w201, and (b) crossplots of trace-element ratios used as redox indices of well w201. Ranges for ratios from Refs. 20, 22.

stantly increasing of $\mathrm{U} / \mathrm{Mo}$ ratio values can be observed from section A to section B (Fig. 5a, Table 2), suggesting that the oxygen content was increasing during section A to section B deposition period. In other words, the reduction tense of palaeo-ocean during section A deposition period is stronger than that of section $\mathrm{B}$, which conforms to the analysis results for major and other trace elements above.

\section{Sedimentary characteristics}

Pyrite occurrences may also be used to identify redox-conditions of palaeo-ocean and formation wa- ter, syndeposit pyrite and pyrite formed by formation water can be observed in Long $\mathrm{I}^{1}$ Submember from Well W201 cores both and more pyrite can be observed in section A cores compared with section B. Besides, the syndeposit pyrite layer in section A is thicker than that of section B (Fig. 4c,d), small coalball-shaped pyrites $7.3-13.6 \mu \mathrm{m}$ in diameter and may reaching $20 \mu \mathrm{m}$ at most in section $\mathrm{A}$, and 5.7-9.8 $\mu \mathrm{m}, 11.4 \mu \mathrm{m}$ in section B (Fig. 4e,f), which is in agreement with the test results of $\mathrm{DOP}_{\mathrm{T}}$. Furthermore, the rock grain size of section $A$ is smaller than that of section $B$, which also confirms 
to the distribution characteristics of major and trace elements.

\section{CONCLUSIONS}

From the geochemical analysis on major and trace and elements patterns of section A and section B from Wells W201 and N1 in the Southern Sichuan Basin, we can reach the following conclusions:

(a) The palaeo-oceans during the section $\mathrm{A}$ and $B$ deposition period were both reducing water in a deep-shelf environment, but there was a subtle reducing strength difference between section $A$ and $B$. The reduction strength of section $A$ is greater than that of section $\mathrm{B}$ by using $\mathrm{DOP}_{\mathrm{T}}$ and $\mathrm{U} / \mathrm{Th}$ ratio analysis. The analysis results show that section $\mathrm{A}$ deposit stage is in a dysoxic environment, and section B an oxic to dysoxic environment. Meanwhile, the sedimentary characteristics show that pyrite are concentrated mainly in the dysoxic environment, but less concentrated in the oxic to dysoxic environment.

(b) If shale samples are calcined before the trace elements test, $\mathrm{V}$ and $\mathrm{Ni}$ test results may have errors, resulting in the fact that the indices including $\mathrm{V} / \mathrm{Cr}, \mathrm{Ni} / \mathrm{Co}$ and $\mathrm{V} /(\mathrm{V}+\mathrm{Ni})$ cannot be applied to the palaeo-redox restoral. For Longmaxi Formation shale, the $\mathrm{DOP}_{\mathrm{T}}$ and $\mathrm{U} / \mathrm{Th}$ ratio can be used as the best redox indices.

(c) Two sections mentioned above may be further divided into 4 subsections named a, b, c, and $\mathrm{d}$ based on the demanding for production. Geochemical characteristics of these subsections will be analysed in the future.

Acknowledgements: This study was financially supported by the Science \& Technology Department of Sichuan Province (No. 2015SZ0001-3).

\section{REFERENCES}

1. Chen XJ, Bao SJ, Hou DJ, Mao XP (2012) Methods and key parameters for shale gas resource evaluation. Petrol Explor Dev 39, 605-10.

2. Murray RW, Buchholtz ten Brink MR, Gerlach DC, Russ III GP, Jones DL (1992) Interoceanic variation in the rare earth, major, and trace element depositional chemistry of chert: Perspectives gained from the DSDP and ODP record. Geochim Cosmochim Acta 56, 1897-913.

3. Smolarek J, Trela W, Bond DPG, Marynowski L (2017) Lower Wenlock black shales in the northern Holy Cross Mountains, Poland: sedimentary and geochemical controls on the Ireviken Event in a deep marine setting. Geol Mag 154, 247-64.
4. Abanda PA, Hannigan RE (2006) Effect of diagenesis on trace element partitioning in shales. Chem Geol 230, 42-59.

5. Murphy AE, Sageman BB, Hollander DJ, Lyons TW, Brett CE (2000) Black shale deposition and faunal overturn in the Devonian Appalachian Basin: Clastic starvation, seasonal water-column mixing, and efficient biolimiting nutrient recycling. Paleoceanogr Paleoclimatol 15, 280-91.

6. Li YF, Shao DY, Lv HG, Zhang Y, Zhang XL, Zhang TW (2015) A relationship between elemental geochemical characteristics and organic matter enrichment in marine shale of Wufeng Formation-Longmaxi Formation, Sichuan Basin. Acta Petrol Sin 36, 1470-83, [in Chinese].

7. Wang SF, Dong D, Wang Y, Li X, Huang J, Guan Q (2016) Sedimentary geochemical proxies for paleoenvironment interpretation of organic-rich shale: A case study of the Lower Silurian Longmaxi Formation, Southern Sichuan Basin, China. J Nat Gas Sci Eng 28, 691-9.

8. Pu BL, Jiang YL, Wang Y, Bao SJ, Liu XJ (2010) Reservoir-forming conditions and favorable exploration zones of shale gas in Lower Silurian Longmaxi Formation of Sichuan Basin. Acta Petrol Sin 31, 225-30, [in Chinese].

9. Li YZ, Wang XZ, Wu B, Li GQ, Wang D (2016) Sedimentary facies of marine shale gas formations in Southern China: The Lower Silurian Longmaxi Formation in the southern Sichuan Basin. $J$ Earth Sci 27, 807-22.

10. Zhao SX, Yang YM, Zhang J, Wang LS, Wang XZ, Luo C, Tian C (2016) Micro-layers division and fine reservoirs contrast of Lower Silurian Longmaxi Formation shale, Sichuan Basin, SW China. Nat Gas Geosci 27, 470-87, [in Chinese].

11. Rimmer SM (2004) Geochemical paleoredox indicators in Devonian-Mississippian black shales, Central Appalachian Basin (USA). Chem Geol 206, 373-91.

12. Wedepohl KH (1971) Environmental influences on the chemical composition of shales and clays. Phys Chem Earth 8, 305-33.

13. Wignall PB, Myers KJ (1988) Interpreting benthic oxygen levels in mudrocks: A new approach. Geology 16, 452-5.

14. Condie KC (1993) Chemical composition and evolution of the upper continental crust: Contrasting results from surface samples and shales. Chem Geol 104, 1-37.

15. Webb GE, Kamber BS (2000) Rare earth elements in Holocene reefal microbialites: a new shallow seawater proxy. Geochim Cosmochim Acta 64, 1557-64.

16. Boström K, Kraemer T, Gartner S (1973) Provenance and accumulation rates of opaline silica, $\mathrm{Al}, \mathrm{Ti}, \mathrm{Fe}$, $\mathrm{Mn}, \mathrm{Cu}, \mathrm{Ni}$ and $\mathrm{Co}$ in Pacific pelagic sediment. Chem Geol 11, 123-48.

17. Tribovillard N, Algeo TJ, Lyons T, Riboulleau A 
(2006) Trace metals as paleoredox and paleoproductivity proxies: An update. Chem Geol 232, 12-32.

18. Ross DJK, Bustin RM (2009) Investigating the use of sedimentary geochemical proxies for paleoenvironment interpretation of thermally mature organic-rich strata: Examples from the Devonian-Mississippian shales, Western Canadian Sedimentary Basin. Chem Geol 260, 1-19.

19. Raiswell R, Buckley F, Berner RA, Anderson TF (1988) Degree of pyritization of iron as a paleoenvironmental indicator of bottom-water oxygenation. J Sediment Res 58, 812-9.

20. Jones B, Manning DAC (1994) Comparison of geochemical indices used for the interpretation of paleoredox conditions in ancient mudstones. Chem Geol 111, 111-29.

21. Sageman BB, Murphy AE, Werne JP, Ver Straeten CA, Hollander DJ, Lyons TW (2003) A tale of shales: the relative roles of production, decomposition, and dilution in the accumulation of organic-rich strata, Middle-Upper Devonian, Appalachian basin. Chem Geol 195, 229-73.

22. Hatch JR, Leventhal JS (1992) Relationship between inferred redox potential of the depositional environment and geochemistry of the Upper Pennsylvanian (Missourian) Stark Shale Member of the Dennis Limestone, Wabaunsee County, Kansas, USA. Chem Geol 99, 65-82.

23. Dean WE, Gardner JV, Piper DZ (1997) Inorganic geochemical indicators of glacial-interglacial changes in productivity and anoxia on the California continental margin. Geochim Cosmochim Acta 61, 4507-18. 